\title{
The Polysemy of Khiläl: A Cognitive Approach
}

\author{
Sameerah T. Saeed ${ }^{1}$ \\ ${ }^{1}$ Ishik University, Erbil, Iraq \\ Correspondence: Sameerah T. Saeed, Ishik University, Erbil, Iraq. Tel: 964-750-420-1189. E-mail: \\ samira.saeed@ishik.edu.iq \\ Received: September 14, 2017 Accepted: November 19, 2017 Online Published: February 4, 2018 \\ doi:10.5539/ijel.v8n3p141 \\ URL: http://doi.org/10.5539/ijel.v8n3p141

\begin{abstract}
This paper presents a cognitive analysis of the Arabic preposition khilāl "through" on the basis of Tyler \& Evans' (2001, 2003) model of Principled Polysemy. The study includes developing a semantic or polysemous network of khilāl through applying the criteria of this model, identifying its primary sense and distinct senses. The study also includes a contrastive analysis of the semantic networks of khiläl and the equivalent English preposition through in terms of their proto-scenes and the distinct senses associated with each. Analyses showed that both khilāl and through share the same proto-scene of a Trajector Traversing a bounded Landmark. Moreover, khiläl seems to have very limited uses comparing to through and this, as I assume, might be due to its restricted use in Modern Standard Arabic, decreasing as a result its pragmatic strengthening possibilities.
\end{abstract}

Keywords: polysemy network, khilāl "through", image schema, proto-scene

\section{Introduction}

In this paper, I treat and refer to khilāl as a preposition despite its classification in most Arabic grammar books as a non-true preposition. Khilāl is one of those elements such as ?mām "in front of", khalf"behind", qabl "before", basd "after", fawq "on/ above", taht "under", which in Arabic grammar are classified as nouns or adverbs of place. Such elements are similar to a large extent to true prepositions, such as min "from", Pla "to", hata "until", $f i$ "in", San "away from", Sala "on" syntactically and semantically, yet not identical to them due to their nominal origin. In modern linguistics, Badawi, Carter, \& Gully (2004, p. 174) label the non-true prepositions as "prepositionals", whereas Abu-Chacra (2007, p. 55) refers to them as "secondary prepositions", which are, according to him, "formed from (verbal) nouns by means of the accusative ending - $a$ ". Other suggested labels are "quasi-prepositions" by Kouloughli (1994, p. 152) and "semi-prepositions" by Ryding (2005, p. 367). Since the present paper does not focus on the syntactic structure of these elements including the case of khilāl, I will simply refer to the latter as a preposition. (Note 1)

The polysemy of the Arabic spatial prepositions in general and khilāl "through" in particular has not been analysed within the framework of cognitive linguistics, except the recent thesis by Peate (2012). Nevertheless, khilāl is not included or examined in his work. The polysemy analysis I develop will build on Tyler \& Evans' (2001, 2003) systematic study of spatial prepositions. Using a systematic methodology, Tyler \& Evans (2001, 2003) establish a wide semantic network of spatial prepositions. The semantic network of a preposition is composed of a proto-scene and several distinct senses which are derived by means of certain cognitive principles.

The investigation of khilāl polysemy shows that it has a similar prototypical scene to English through-they describe a spatial relation of a Trajector traversing a bounded Landmark with an entrance point and exit point. Furthermore, one distinct sense can be derived from this primary sense, namely the Temporal sense. Moreover, contrasting the distinct senses associated with khiläl in Arabic and through in English shows that the former has less uses due to the limited pragmatic strengthening and reconceptualization being associated with it. The Arabic examples provided are mostly cited from the arabiCorpus; a few are mine. (Note 2)

The paper is organised as follows. Section 2 introduces some basic cognitive notions and terminology. Section 3 investigates and applies the criteria of Tyler \& Evans' (2001, 2003) Principled Polysemy to khilāl. A review of the semantic network of through and a comparison of the polysemy network of khiläl and through will be presented in section 4 discussing the poor semantic network of khiläl. Section 5 concludes the paper. 


\section{Basic Notions}

Below is a brief introduction to some preliminary notions and terms that are commonly used in the literature on spatial prepositions within the framework of cognitive linguistics and that will be used also in the following analysis of khilāl.

\subsection{Prepositions and Polysemy}

A traditional definition of a preposition is given by Huddleston \& Pullum (2002, p. 589), who define it as a "word that governs, and normally precedes, a noun or pronoun and which expresses the latter's relation to another word". Traditional grammarians mostly characterise prepositions as closed-class or grammatical words linking other words, rather than as words with lexical meanings. Moreover, if they are classified as lexical words, prepositions in traditional linguistics are seen as forms that have a list of idiosyncratic meanings denoting position, time, manner, means, etc. With regards to polysemy, traditional approaches to grammar mostly view this as a "matter of different senses being listed under a single lexical entry" (Falkum, 2011, p. 9). Thus, traditionally a polysemous item is taken to have multiple unrelated meanings. (Note 3)

A cognitively-oriented approach views polysemy differently and thus characterises prepositions differently. Cognitive linguists define polysemy as a phenomenon whereby a lexical item is associated with a range of meanings derived from a single basic meaning (Tyler \& Evans, 2001, 2003; Croft \& Cruse, 2004; Brugman \& Lakoff, 2006, amongst others).

Prepositional polysemy has been widely researched by cognitive linguists and various theories and principles have been invoked to account for the polysemy network of prepositions, such as Prototype Theory (Rosch, 1973, 1975a, 1975b; Smith, Shoben, \& Rips 1974; Rosch \& Mervis, 1975), radial categories (Lakoff 1987) and Principled Polysemy (Tyler \& Evans, 2001, 2003). These models have played an important role in work on polysemous forms, among which are prepositions. The polysemy of a spatial preposition is typically viewed as involving a network of multiple related meanings surrounding a prototypical meaning (Lakoff, 1987; Taylor, 2003).

The analysis of spatial prepositions within the framework of cognitive linguistics seems plausible in terms of developing an analysis of their polysemy. For example, the semantic network of through put forward by Tyler \& Evans (2003) is the most detailed account that is available in the literature of through. Several useful cognitive concepts are employed for this purpose, such as proto-scene, image schema transformation, semantic network, principled polysemy and metaphorical mapping. They all aim to account for the very wide range of senses that have developed from one single primary sense.

\subsection{Trajector and Landmark}

In cognitive linguistics, the notions of Trajector (TR) and Landmark (LM) are used as "specific manifestations of the Figure/Ground principle in relations encoded by prepositions" (Schmid, 2007, p. 128). The terms Figure and Ground were originally used in Gestalt psychology (Note 4) and introduced into cognitive linguistics by Talmy (1975). In a given configuration, the Figure is the most prominent entity while the Ground is less so. However, Langacker (1987) suggested two parallel terms: Trajector and Landmark, which characterize respectively the Figure and Ground in a spatial configuration designated by prepositions. Thus, following Langacker's terms, in a prepositional configuration the TR and LM stand for the two objects, entities, events, etc., which are related via a preposition. For instance, in a spatial prepositional relation that involves $\mathrm{X}$ being located at/in/near/over/below/etc. Y, the TR would be X and the LM would be Y. Consider the following examples, all taken from the British National Corpus (BNC):

(1) a. He (TR) stayed beside the car (LM) as she crossed the narrow pavement. (BNC, W_fict_prose)

b. A child (TR) in the car (LM) was among the injured. (BNC, W_newsp_tabloid)

c. I (TR) once went to the House of Commons (LM) to see how the country was run. (BNC, W_newsp_tabloid)

d. Jo (TR) was some 10 yards behind me (LM) near the corner (LM). (BNC, W_misc)

In all these examples, the TR refers to an entity located or moved with reference to an LM which is again an object or a location. The TR and LM are distinct from each other in terms of size (the TR is usually smaller), prominence (the TR is more prominent), mobility (the TR is more mobile) and reiteration (there can sometimes be more than one LM, as in 1d), etc. (see Croft \& Cruse, 2004, p. 56 for further details). 


\subsection{Image Schema}

The notion of "image schema", as characterised by Johnson (1987, p. xiv), is a "recurring dynamic pattern of our perceptual interactions and motor programs that gives coherence and structure to our experience". He further argues that "these patterns emerge primarily as meaningful structures for us chiefly at the level of our bodily movements through space, our manipulation of objects, and our perceptual interactions" (ibid, p. 29). In other words, image schemas are abstract depictions that derive or result from our embodied experience that occur repeatedly as we interact with objects in the world. For example, through experiencing several instances of objects being inside others, humans acquire a mental abstract depiction or image of containers or containment. This image schema is then used to understand and conceptualise other similar spatial and abstract examples of containment. Other examples of image schemas, as listed by Lakoff (1987, p. 267), are "PATHS, LINKS, FORCES, BALANCE,...UP-DOWN, FRONT-BACK, PART-WHOLE, CENTER-PERIPHERY, etc.” (Note 5)

Image schemas have proven a useful tool for the cognitive semantic analysis of prepositions as well as other linguistic elements. For example, the process of image schema transformations plays a central role in constructing radial categories of senses (Brugman \& Lakoff 2006, p. 133). In the analysis of the polysemy of $k h i l a \bar{l}$, these notions will be further explained and elaborated as several image schemas will be provided to represent the core sense and distinct senses. (Note 6)

\subsection{Metaphor and Metaphorical Mapping}

Another relevant notion is metaphor. The latter is traditionally "based on the notions of "similarity" or "comparison" between the literal and the figurative meaning of an expression" (Ungerer \& Schmid, 1996, p. 115). However, within cognitive linguistics, metaphor is not restricted to the classical view as being a figure of speech in literary work. Instead, in cognitive linguistics, metaphor is used to refer to a "cross-domain mapping in the conceptual system" (Lakoff, 2006, p. 186). The two conceptual domains involved in metaphoric concepts are called the source domain and the target domain. The source domain usually has a physical concrete existence, involving objects or physical actions, while the target domain is a more abstract one, involving thoughts or emotions. The source domain is used to understand and conceptualize the target domain. The relationship that exists between the two domains is a mapping, more specifically a metaphorical mapping which occurs in our conceptual system (human thought). Consequently, in cognitive analysis, metaphors are viewed not only as linguistic tools; rather they are considered fundamental in our way of thinking.

Lakoff (2006, p. 199) put forward the "Invariance Principle" to account for certain properties of the process of metaphorical mapping. According to this principle, "source domain interiors correspond to target domain interiors; source domain exteriors correspond to target domain exteriors, and so forth". Moreover, it "hypothesizes that image-schema structure is always preserved by metaphor" (Lakoff, 2006, p. 200).

In their famous example LOVE IS A JOURNEY, Lakoff \& Johnson (1980, pp. 45-46) point out that love (target domain) is often understood as a journey (source domain). This is possible because all the components involved in a journey are to be found in a love relationship, thus they are corresponding to each other in several aspects. Travellers in the journey domain can be mapped onto lovers in the love domain, the vehicle can be mapped onto the love relationship, obstacles encountered in journeys can be mapped onto problems or difficulties experienced in love relations, and so on (Evans \& Green 2006, p. 295). (Note 7)

Metaphors are used, amongst others, in the semantic analysis of (spatial) prepositions, in which metaphor facilitates or allows the extension of a spatial meaning of a preposition into a non-spatial one. More specifically, both image schema transformation and metaphors play an important role in building up the polysemy of prepositions (see sections 3 for more discussion and examples).

\section{The Semantic Network of KhiläL}

The Arabic preposition khiläl "through" is used to denote a few senses varying between spatial and non-spatial notions. In Arabic, khilāl is used to denote mostly temporal (2a), not many spatial (2b) and many metaphorical notions (2c). (Note 8,9)

\begin{tabular}{|c|c|c|c|}
\hline $\begin{array}{l}\text { 2) a. tawașalat } \\
\text { continue.PST.F3SG } \\
\text { "The efforts of de }\end{array}$ & $\begin{array}{l}\text { juhūd-u } \\
\text { efforts-NOM } \\
\text { elopment con }\end{array}$ & $\begin{array}{l}\text { at-tațwīr-i } \\
\text { DEF-development-GEN } \\
\text { lued through 1995." (ara }\end{array}$ & $\begin{array}{l}\text { khilāl (Note 10) } \\
\text { through } \\
\text { Corpus, Hayat97) }\end{array}$ \\
\hline b. marat & al-fiiprān & khilāl thuqb-in & șaghīr \\
\hline
\end{tabular}


"The mice passed through a small hole."

\begin{tabular}{|c|c|c|c|c|}
\hline c. Pahdar-nā & furaș-an & kathīrah & khilāl & al-mubārāt \\
\hline lose.PST-1PL & opportunities-ACC & a lot & through & DEF-match \\
\hline
\end{tabular}

In this section, I will examine the polysemy network of khilāl within the cognitive framework. This includes identifying its primary sense (the proto-scene) and the distinct sense(s) associated with it. For this purpose, I will follow and apply Tyler \& Evans' (2001, 2003) model of Principled Polysemy which has proven useful in the analysis of several prepositions in e.g., English (see in particular Tyler \& Evans 2003).

The model of Principled Polysemy has been proposed by Tyler \& Evans (2003). It holds that a "particular form... is conventionally associated with a number of distinct but related meanings" and that these senses are "related to each other in a systematic and motivated way" (ibid, pp. 37-38). This model provides a constrained methodology for determining the primary sense of a preposition among the several senses and uses of the preposition, which together form the semantic network of prepositional polysemy. They refer to the central or core meaning as the proto-scene (ibid, p. 26) upon which several distinct but related senses are derived. Applying the model of Principled Polysemy, Tyler \& Evans (2003) have examined the semantic networks of many English prepositions, such as over, above, under, below, up, down, in front of, behind, in, to and through. In the following subsections, I will present and apply these criteria to build the polysemy network of the Arabic preposition khilāl.

\subsection{The Proto-scene of Khilāl}

In all the examples given in (2a-c), khilāl mainly denotes a path spatial notion where a TR is traversing a bounded LM. This is very evident in the spatial use exemplified in (2b); the TR alfi?rān "the mice" are entities which moved within the limits of the bounded LM thuqb "hole". Similarly, in (2a), the TR juhüd altatwīr "the efforts of development" can be conceptualised as an entity passing in the course of a specific time, the LM $९ \bar{a} m$ 1995 "the year of 1995". With regard to (2c), the TR is furas "opportunities" which can be conceived of as an entity that has been traversing the time course taken up by the match, the LM.

However, before we can assert that this notion, common to all these examples, represents the proto-scene of khiläl, an investigation of the fuller data needs to be carried out with the use of Tyler \& Evans' (2001, 2003) criteria for identifying the proto-scene of a preposition. This has a two-fold purpose; first to precisely determine the proto-scene of the Arabic preposition khiläl, and second to investigate the applicability of these criteria, in order to determine if they are principled and systematic and constrain arbitrariness in identifying the primary sense of a preposition.

Tyler \& Evans $(2001,2003)$ propose a set of five linguistic criteria that can determine the proto-scene of a spatial preposition; these are "earliest attested meaning,... predominance in the semantic network,... use in composite forms, ... relations to other spatial particles, and... grammatical predictions" (2003, p. 47). Below, each of these criteria will be applied to the meanings denoted by khilāl as exemplified in (2a-c) and other examples.

To start with, Tyler \& Evans (2003, p. 47) argue that the "historically earliest sense" of a preposition is likely to be the primary sense, and that despite the association of several other meanings to a preposition, the core or primary sense is normally expected to be stable over time. For the various English prepositions that they analysed, they interestingly found that the "earliest attested uses have to do with a spatial configuration holding between the TR and the LM" (ibid). For example, in their analysis of through, they found that diachronic studies of through shows that the spatial meaning of a TR traversing an LM in e.g. the train runs through the tunnel, was historically earlier than its non-spatial meanings, such as Means as in she contacts her supervisors through emails.

With regard to the Arabic preposition khiläl, it appears that there has been no diachronic study of its meaning. Etymologically, there may be a connection with the verb takhalal "to penetrate; enter; pass through the midst of (people)" (Wortabet, 1888, p. 146) or the noun khiläl "gap, interval" (Wehr, 1976, p. 252), but this does not really tell us much. More relevant may be the meaning of khiläl in Qur'an, which represents an earlier stage of the language. The Arabic-English Dictionary of Qur'anic Usage (Badawi \& Abdel Haleem, 2008, p. 284) lists only one relevant meaning for khilāl, which is referred to as an adverbial use: "(small gaps, breaches, openings) through, amongst, between, within". Illustrative examples are:
(3) a. fa-tufajira
al-?anhār-a
khilāl-hā
then-explode
DEF-rivers-ACC through-POSS.3SG 
"Then you cause the rivers to gush forth through it." (Qur'an, Al-Isra 91)

\author{
b. fa-tara al-wadaq-a yakhruju min khilāl-ih \\ then-see DEF-rain-ACC exit.PRS.3SG from through-POSS.3SG
}

“Then you see the rain coming out from its midst." (Qur'an, Al-Rum 48)

The meaning expressed by khilāl in these two Qur'anic passages is that of an object penetrating another object that is bigger or wider in space. Both TRs, alPanhār "the rivers" in (3a) and alwadaq "the rain" in (3b), penetrate an object which is represented by the suffixal possessive pronouns $-h \bar{a}(3 a)$ and $-i h(3 b)$. The referential antecedents of these pronouns are janna "heaven" and kisafan "a layer of clouds", respectively. In the process, the TRs move from one side of the LMs to the other; thus there is an entrance and an exit point so that the Qur'anic examples in (3) therefore support the idea that the spatial configuration of penetration or traversing of a TR from one side of an LM to the other was the earliest sense of khilāl, which may suggest that this is still the primary sense of the word today.

The second criterion to identify a primary sense is predominance within a semantic network. According to this notion, the primary sense is the most dominant that is available in most of the distinct senses associated with a preposition. In all the examples so far given, (2)-(3), the spatial notion of a TR penetrating or traversing an LM has been recognised, hence supporting the conclusion reached at so far by the application of the first criterion. (Note 11)

As to the third criterion, use in composite forms, Tyler \& Evans (2003, p. 48) argue that the absence of a specific sense of a preposition in a composite form such as compound and verb particle forms is an indicator that this specific sense is not a primary sense. This, thus, helps narrowing down the range of senses in determining the primary sense. This criterion is, however, not applicable as composite forms are not common to Arabic, hence I will disregard it.

Turning to the criterion of relation to other prepositions, Tyler \& Evans (2003) suggest that spatial prepositions can be grouped into certain sets. For example, over, above, under and below form one coherent set. This means that the primary sense of e.g., over is likely to be the sense that distinguishes it from the rest in the set. That is, if over denotes the spatial notion of a TR being "higher than but potentially within reach of the LM" (ibid, p. 49), and under denotes the notion of the TR being lower but probably within reach of the LM, this particular sense of over which contrasts with under is likely to be the primary sense. In case of the Arabic khilall, I propose that it can be grouped with the preposition Sabra "across", because in both the TR follows a path inside or along an LM. The difference between khiläl and Sabra can be attributed to the LM dimension type. That is, while khiläl requires a two- or three-dimensional LM, Sabra requires a one-dimensional LM. See examples below:

$\begin{array}{cll}\text { (4) a. sir-nā } & \text { khilāl } & \text { al-ḥadīqa } \\ \text { walk.PST.1PL } & \text { through } & \text { DEF-garden }\end{array}$

"We walked through the garden."

b. thahab-nā Sabra al-ḥadīqa

go.PST-1PL across DEF-garden

"We went across the garden."

Although in both (4a and b) the TR (the speaker) follows a path with reference to the LM alhadiqa "the garden", the latter is conceptualised differently in terms of dimensionality. In (4a) alhadīqa is conceived of as a three dimensional space, whereas in (4b) it is seen as an entity with one or two dimensions. It is worth noting that this distinction between khiläl and Sabra is similar to the distinction between the English through and across, respectively, as discussed in Quirk et al. (1985). Thus, we conclude that the primary sense of khilāl is likely to be the one that distinguishes it from Sabra, with which it forms a set.

Finally, Tyler \& Evans (2003) argue that grammatical predictions help to determine a primary sense and to distinguish it from a distinct sense derived directly or indirectly from it. A distinct sense is usually created and added to the semantic network of a preposition due to extension and routinization of the primary sense (Langacker, 1987; Tyler \& Evans, 2003). According to this criterion, there should be sentences where the "context provides the implicature that gives rise to the additional meaning associated with the distinct sense" (ibid 49). To say this differently, the sense that is more likely to be the primary sense is the one which in certain sentences, along with contextual elements, gives rise to a different but related sense and not the reverse. Consider the examples in (5) for khiläl: 
$\begin{array}{cllll}\text { (5) a. hunāk } & \text { tayārāt } & \text { qawiyah } & \text { tajry khilāl al-burj } \\ \text { there } & \text { currents } & \text { strong } & \text { move.PRS through } & \text { DEF-tower }\end{array}$

"There are strong currents moving through the tower."

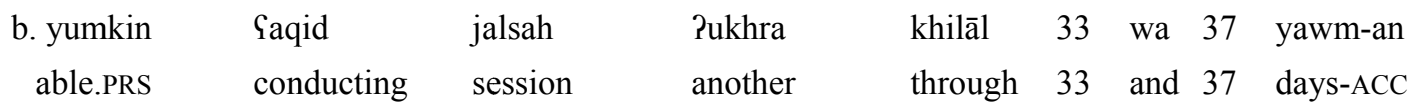

"Another session can be held within 33 and 37 days." (arabiCorpus, WORL)

In (5a), khilāl denotes the spatial notion of a TR traversing a bounded LM, which the evidence so far suggests is its primary sense. In contrast, $(5 \mathrm{~b})$ demonstrates a non-spatial sense, where jalsah "session", the TR, is supposed to be held via the time domain represented by the LM. That is, the TR traverses a non-spatial LM from one side of it to the other and as a result something is achieved. Therefore, the notion of grammatical prediction helps us determine that, of the two uses of khiläl, (5a) and (5b), the former is more likely to be the primary sense rather than the other because the non-spatial sense of khiläl is reached on the basis of the primary sense as well as the contextual elements available, which is the time element given.

To conclude, the criteria (except the third one) set forth by Tyler \& Evans $(2001,2003)$ for determining the primary sense of a preposition, when applied to the Arabic preposition khilal unanimously show that the primary sense of khilāl is that of a TR traversing a spatial bounded LM with an entrance and exit ending. The proto-scene of khiläl can, therefore, be represented schematically as in figure 1, which resembles the proto-scene of through as cited from Tyler \& Evans (2003, p. 219).

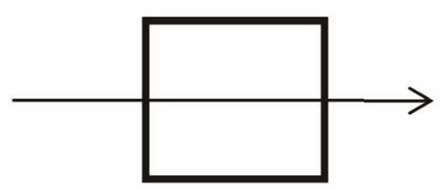

Figure 1. The proto-scene of khilāl

Due to this parallelism between khiläl and through in terms of their proto-scenes, the same functional element of path can be said to associate with khiläl. This is quite apparent in the examples provided above, for instance, in (5a) the TR tayārāt "currents" follows a path while traversing the LM alburj "the tower".

\subsection{The Distinct Sense(s) of Khilāl}

As has been determined in the previous subsection, the proto-scene of khilāl involves a TR traversing a bounded LM with an entrance and exit point. Out of this sense, several other senses can be derived and together they form the semantic network of this preposition. The derivation of these senses reflects the rich spatial conceptualization of the proto-scene and the tight correlations between our spatial experience of the world and our non-spatial experience. To identify the range of other senses, I will apply Tyler \& Evans (2001, 2003) two criteria for determining the distinct senses associated with a preposition. Tyler \& Evans (2003, pp. 42-44) state: "For a sense to count as distinct, it must contain additional meaning not apparent in any other senses associated with a particular form, ... [and] ... there must be instances of the sense that are context independent".

Both of these criteria will be applied and tested for determining the distinct senses associated with khiläl. In the arabiCorpus, and at the time of writing this paper, the total occurrence of khilal reaches 299,100. Of all of these a sample of 2500 citations have been checked and observed carefully.

Below I will cite examples of the most common repeated uses. The examples which show similarity are grouped together. To start with, in the Arabic dictionaries such as Arabic-English Dictionary of Qur'anic Usage (2008, p. 284) and Al-Mawrid Dictionary (1995, p. 519), the preposition khilāl or min khilāl is also translated into the English words between and among. The latter two denote the notion of choice involving two or more items. In Arabic, khilāl denotes such a sense to a certain extent but in a spatial way. Consider:
(6) rāhat ash-shams-u tațulu
$\min$
khilāl
al-ghyūm
start.PST.F3SG
DEF-sun-NOM rise.PRS.3SG from
through DEF-cloud

"The sun started to rise through the clouds." (arabiCorpus, Hayat96) 
In the interpretation of the sentence, the TR, ashshamsu "the sun" is the entity that traverses the LM alghyum "the clouds" and this is quite similar to the proto-scene determined earlier. On the other hand, min khiläl can be paraphrased into min bein "from between", thus denoting multiple LMs. This is not a distinct sense; it is rather a variation of the spatial notion of khiläl (or min khilāl), namely that of TR traversing a multiple LM.

A very common use of khilāl is given in (7a-c):

$\begin{array}{cllllll}\text { (7) a. sa-yantahy } & \text { al-Samal } & \text { fì } & \text { hathihi } & \text { al-qā̧̄īdahkhilāl } & 18 & \text { shahr-an } \\ \text { will-end } & \text { DEF-work } & \text { in } & \text { this } & \text { DEF-base through } & 18 & \text { month-ACC }\end{array}$

"The work on this base will end in 18 months." (arabiCorpus, Ahram99)

$\begin{array}{llll}\text { b. taḍāGafat } & \text { al-mushkilah khilāl } & \text { al-qarn-ein } & \text { al-Pakhīr-ein } \\ \text { double.PST.F3SG } & \text { DEF-problem through } & \text { DEF-decade-DU } & \text { DEF-last-DU }\end{array}$

"The problem has doubled through/ in the last two decades." (arabiCorpus, Hayat97)

c. tama al-i̧lān khilāl mu?tamar ibson ad-duwalī

do.PST DEF-announcement through conference Ibsen DEF-international

"The announcement was revealed during Ibsen international conference." (arabiCorpu, Hayat96)

In the interpretation of (7a-c), khilall is followed by DPs denoting temporal domains: 18 shahran "18 months", alqarnein al?akhïrein "the last two decades" and mu?tamar ibson adduwalī "Ibsen international conference", respectively. Similar to the English preposition through, the Arabic preposition khiläl can thus be said to denote Temporal sense. This sense is due to the correlation between an extended action or event and a period of time. In (7a), for instance, the TR al Samal fi hathihi alq $\bar{a} \bar{l}_{\bar{l}} d a h$ "work on this base" is an extended action composed of a series of sequential components and carried out by agents which are not overt in the example. The action takes place over a specific period of time expressed by the LM 18 shahran "18 months". Hence, there is a temporal relation between the TR and the LM, which results in the Temporal sense being associated with khiläl. The spatial movement of a TR inside a bounded LM is mapped metaphorically into a movement within a temporal domain. The same explanation applies to khiläl in (7b).

With regard to (7c), the LM is not a direct temporal domain, but rather an event which takes place in a specific place and time. The place of the event is not relevant in the interpretation of khilāl in this context. It is rather the period of time taken by the event. That is, the TR alislān "the announcement", which is an event, correlates with the specific time. In other words, the TR traverses the time domain of the conference, hence the Temporal sense of khiläl. Figure 2 shows its schematic representation. The TR is the empty circle, the dotted arrow is the path followed by the TR along the time of the LM which is represented by the straight line.

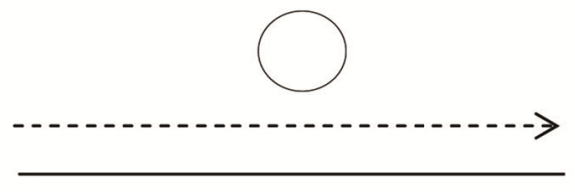

Figure 2. The schematic representation of the Temporal sense

Applying the two criteria of Tyler \& Evans (2001, 2003) for determining a distinct sense further supports the association of the Temporal sense to khiläl. Firstly, the Temporal sense satisfies the first criterion in that it is distinct from the spatial sense so far determined for khiläl-its proto-scene. While the LM of the primary spatial sense of khiläl involves spatial bounded concrete objects with two endings (entrance and exit), in the temporal sense these objects are metaphorically mapped into actions and events taking place in a specific time. Second, there are several instances, such as (7c), where the Temporal sense is not gained from a direct contextual element as has been the case with (7a-b) where the LM is an explicit time. In fact, it would not be possible to interpret (7c) if we lack the knowledge of a Temporal sense of khiläl. As a result it is necessary to recognise the Temporal sense as a distinct sense in the semantic network of khiläl.

A variation of the Temporal sense can be seen in the combination $f_{i}$ khilal l "within, in the course of, meanwhile, meantime" (Al-Mawrid, 1995, p. 519). Illustrative examples are:
(8) a. izdāda
dakhl-u
al-fard
fī khilāl
hath-ein al-ৎām-ein 
increase.PST.3SG income-NOM DEF-person in through this-DU DEF-year-DU

"People's income has increased in these two years." (arabiCorpus, Hayat97)

b. Panā Pastakhdim-uh faqaṭī khilāl an-nahār

"I use it only during day." (arabiCorpus, sayd)

Another common use of khiläl is that when preceded by the true preposition min "from" forming the complex preposition min khiläl "by means of/ by way of".

$\begin{array}{clllll}\text { (9) a. Sarafū } & \text { San } & \text { al-ḥadath } & \text { min } & \text { khilāl } & \text { barnāmij } \\ \text { know.PST.M3PL } & \text { about } & \text { DEF-event } & \text { from } & \text { through } & \text { programme }\end{array}$

Facebook

Facebook

"They knew about the event through Facebook." (arabiCorpus, AlGhad01)

$\begin{array}{llcccl}\text { b. tamakanat } & \text { al-wizārah } \quad \text { min } & \text { khilāl } & \text { qānūn } & \text { himāyat } \\ \text { able.PST.F3SG } & \text { DEF-Ministry from } & \text { through } & \text { law } & \text { protection } \\ \text { al-bīiah } & \text { min } & \text { al-tașady } & \text { l-l-jarāPim } & \text { al-bīPeeyah } \\ \text { DEF-environment } & \text { from } & \text { DEF-confronting } & \text { for-DEF-crimes } & \text { DEF-environmental }\end{array}$

"The Ministry could confront the environmental crimes through the law of environment protection." (arabiCorpus, AlGhad02)

In both (9a-b), the combination min khilāl expresses a Means sense whereby the LM is conceptualised as an entity (abstract in these two examples) that facilitates the passage of an entity to accomplish an activity. Note that the sense proposed here is not that of completion or achievement. In fact, the TRs are agents who after using the path inside the LMs get to achieve something. For instance, knowing about the event, in (9a), and confronting the environmental crimes, in (9b), are goals or activities accomplished after the TRs - au "-M3PL (meaning they)" and alwizārah "the Ministry" have metaphorically passed the path within the LMs barnämij Facebook "Facebook programme" and qānūn himāyat albī?ah "the law of environment protection", respectively. It is worth noting that this interpretation is reached through adopting a metaphor like MEANS ARE PATHS proposed by Lakoff (2006, p. 204). (Note 12)

Based on this idea, paths can be metaphorically mapped into means. In the spatial sense, the TR follows a path when traversing a bounded LM from one end point to another. Similarly, by metaphorical extension, in the Means sense the TR metaphorically traverses an intermediary entity or event resulting in an accomplishment. Thus, the Means sense is derived by both metaphorical extension and image schema transformation through resembling the image schema of the proto-scene. Figure 3 further illustrates the Means sense expressed in examples (9a-b). The TR (the agents in this case) is represented by an empty circle. It traverses the LM (the means), represented by a bounded rectangle, from one side to the other. The dark circle represents a goal or an accomplishment which can be present or not, depending on the context.

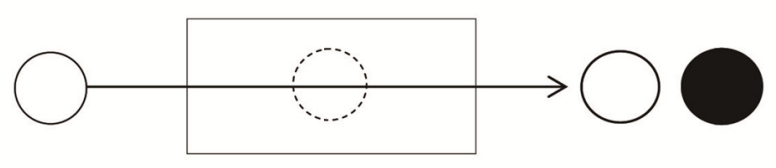

Figure 3. The schematic representation of the Means sense

However, inclusion of the Means sense in the semantic network of khilāl does not seem to satisfy Tyler \& Evans' $(2001,2003)$ both criteria for determining a distinct sense. In terms of the first criterion, the Means sense can be said to satisfy it being identified as a distinct sense, which is different from the proto-scene and the Temporal sense. As for the second criterion, the sentences in (9a-b) are instances of the Means sense, but the issue of being recognised context-independently and thus conventionalised and added to our semantic knowledge of khilāl is questionable. The question that arises here has to do with the role of min "from" in forming the Means sense 
along with khilāl. Although a close examination of the meaning expressed by min khiläl shows that the Means sense is mostly denoted by the second element, that is khilall, interestingly when min "from" is removed, the Means sense does not become valid strongly and the sentence will be ill-formed.
(10) a. *Carafū
San
al-ḥadath khilāl
barnāmij
Facebook
know.PST.M3PL about
DEF-event through
programme
Facebook

"They knew about the event in Facebook."

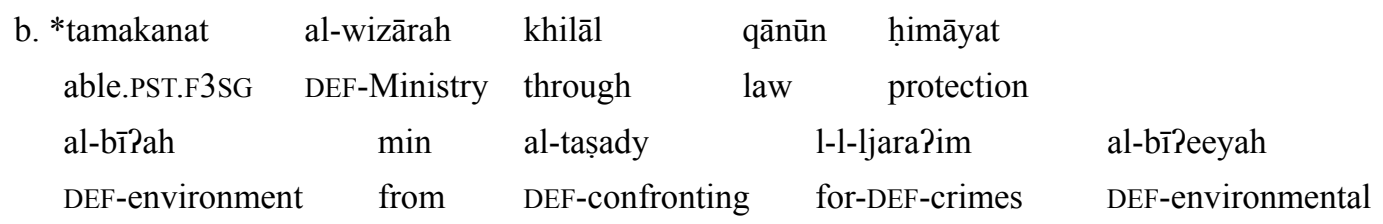

"The Ministry could confront the environmental crimes through the law of environment protection."

Although I kept the English translations as they are, the meaning expressed by khilāl alone does not suggest a Means sense. In (10a), the overall meaning is mostly that of "they knew about the event IN Facebook", which is a spatial use represented by English IN. In (10b), although a sense of Means is expressed, using khilāl alone does not directly or smoothly suggests it. So the Means sense of khiläl seems pending on the presence of min. For more examples, contrast:

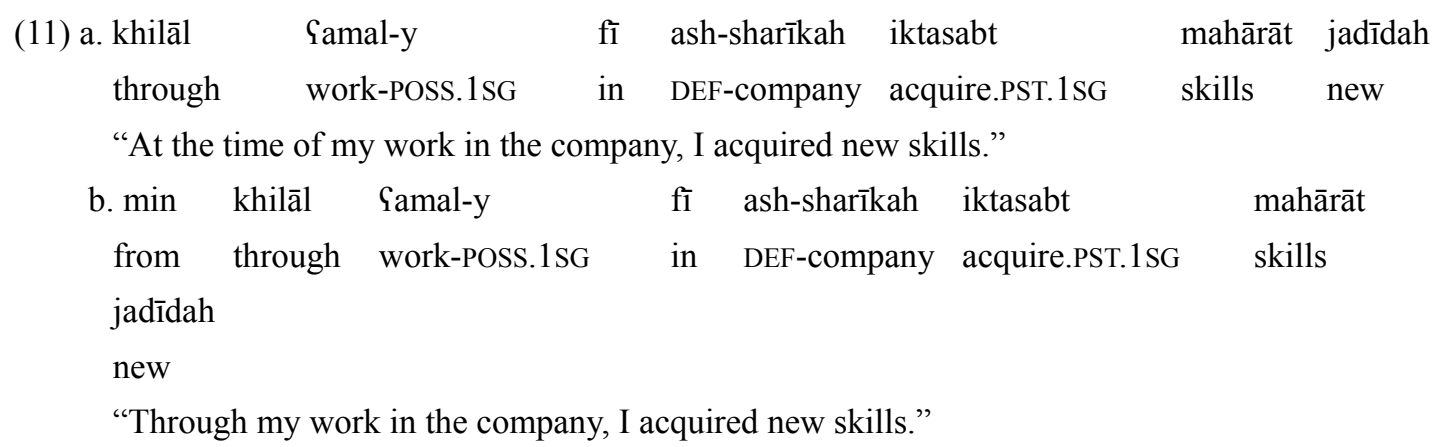

In (11a), khiläl is used alone and the meaning it suggests is that of Temporal. It describes the period of time during which the speaker (the Trajector) has worked in the company. In (11b), khilāl is preceded by min "from" and the meaning suggested by the combination min khilāl is that "of means". Thus, khilāl seems to be distinct from min khilāl. As a result, and taking Tyler \& Evans $(2001,2003)$ two criteria for determining distinct senses as decisive factors, I take the Means sense not to be associated with the semantic network of khiläl, because it is not purely denoted by khiläl, but rather by the complex preposition min khilall "from through", meaning "by means of" or "by way of".

\subsection{The Polysemy Network of KhiläL}

In their model of Principled Polysemy, Tyler \& Evans $(2001,2003)$ posit that the polysemy network of a preposition is composed of a proto-scene and a set of distinct senses. Furthermore, they introduce the notion of cluster to enclose and/or represent those sets of senses that share one image schema (Tyler \& Evans, 2001, p. 747). (Note 13)

In case of the Arabic preposition khilall, only one distinct sense has been identified and determined, which is the Temporal sense. However, since no further distinct senses derive from the image schema of this sense, no clusters are formed. The formation of a cluster might happen in the future if new senses arise and are identified, provided that they share the same image schema.

Thus, we can diagram the polysemy network of khiläl as in figure 4. It is composed of the proto-scene represented by the shaded circle and the Temporal sense represented by the empty circle. 


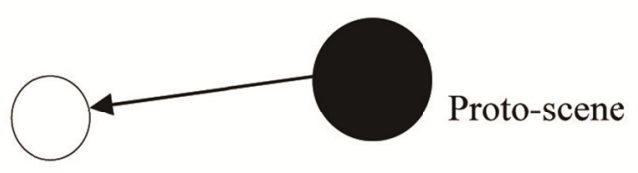

Temporal sense

Figure 4. The polysemy network of khilāl

\section{Comparison to English Through}

\subsection{The Polysemy Network of Through}

In this section, I briefly review the semantic network of the English equivalent preposition through as analysed by Tyler and Evans within their model of Principled Polysemy $(2001,2003)$. They determine a primary sense of through as well as seven distinct senses which together form the semantic network of through. All the examples given in this section are cited from Tyler \& Evans (2003).

Their proto-scene of through encompasses a "spatial configuration involving contiguous location from one side of a bounded LM to the other" (Evans \& Tyler, 2004, p. 247). Thus the proto-scene of through involves an entrance point, an exit point and a trajectory followed by a TR inside a bounded LM. Based on this spatial configuration, the functional element of path is associated with through. This element arises "due to the way we interact with and reach goals" (ibid 266). Tyler \& Evans (2003, p. 219) diagram the proto-scene of through as in figure 5, repeated from figure 1 .

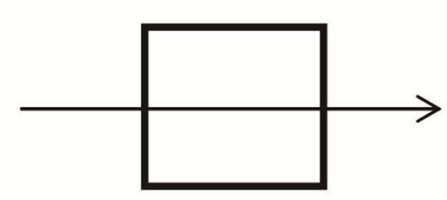

Figure 5. The proto-scene of through

Based on the proto-scene of through, Tyler \& Evans (2003) identify seven distinct senses applying the two criteria that distinguish the distinct senses associated with a preposition (see section 3.2). The senses are the Extended Action sense, the Temporal sense, the On-the-other-side-of sense, the Completion sense, the Transmission sense, the Means sense and the Cause sense. In what follows, I give a brief description of each of these senses, citing examples from Tyler \& Evans (2003).

The Extended Action sense can be associated with through due to the experiential correlation that exists between "motion along a path and purposeful activity" (Tyler \& Evans 2003, p. 221). That is, the entrance point of a spatial LM can correspond to the starting point or the first stage of an activity and the exit point can correspond to the ending or final stage of the activity. In the space between the starting and the ending point, the activity or action is processed or extended, that is, taking place. The continuous movement of TR takes place in the LM and hence "the LM serves to define the sequence of action components which together comprise an extended action or event" (ibid). Illustrative examples are provided below:

(12) a. Lance is halfway through the race.

b. Mary worked through the pages of math exercises.

These examples show that the focus is on the contiguous points in the middle of the LM, where an action is extended.

The second sense distinguished by Tyler \& Evans (2003) is the Temporal one, which arises out of the tight correlation between an extended action and time. Here, through serves to correlate an action carried out or experienced by a TR and a "particular time period for which the action or state continues" (ibid, p. 221). Consider these examples:

(13) a. The young man stood through the entire show.

b. The law students were required to sit through a trial. 
The TRs in both sentences carry out a specific action, namely standing and sitting, for a specific duration identified by the LMs the show and $a$ trial. Thus, the two actions are carried out and extended along a period of time.

The On-the-other-side-of sense can be associated with through based on two factors: "The pragmatic strengthening of the experiential correlate associated with the experiencer travelling a path that transects an LM that is conceptualized as bounded, such as a field or a forest; and (2) the shift in vantage point from off-stage to the entrance point" (ibid, p. 223). That is, the On-the-other-side-of sense is derived from the spatial proto-scene based on the implication that traversing an LM causes the TR to be on the other side of the LM once it leaves its starting position at the entrance side of the LM. That is, once a TR has followed the entire trajectory inside an LM, it must be located at the side of the exit point. This is shown in example (14):

(14) Once she passed through the doorway at the end of the dark hallway, she found herself in a sunny enclosed porch.

The TR she, after going from one side of the LM the doorway to the other, is located at the other side (specifically the exit side) of the LM. Via pragmatic strengthening, this sense has been conventionalized and associated with through. The second factor can be understood through the following example:

(15) My office is located just through that door.

In this sentence, the office is the TR and the door is the LM. What is special about the TR is that it is not experiencing a real traverse through the designated LM. This implies that there is no objective construal of the TR. The sentence can only be interpreted subjectively, that is from the viewpoint of the conceptualizer or the observer. This shift of focus from an objective vantage point to a subjective one was first suggested by Langacker (2000, p. 297) and is referred to as subjectification. According to the notion of subjectification, instead of the TR experiencing a physical motion, there is a mental scanning carried out by the conceptualizer (the speaker in this case).

Another sense identified by Tyler \& Evans (2003) is Completion. This sense is based on the reanalysis of the spatial proto-scene of through where the end point of the trajectory can be understood as the end of an action. Paths come to an end at some point and similarly activities come to an end by being completed at some point. (note 14) This can be conceptualised as a process of starting an activity, working on it and completing it. The latter is the point focused on in the completion sense as it signals the end of an activity, event or process. Consider examples (16a-b):

(16) a. Jane is through with the book.

b. I'm through with all these fad diets.

In (16a), the TR has gone through a series of steps to complete the activity of reading the book. The TR has metaphorically traversed through the LM the book and the traversing is reflected in the reading process. Likewise, in (16b), the TR experiences the feeling of reaching a decision after trying several diets. Thus, when the addressee reaches the exit point, it signals the completion of a process.

For the last three senses of through distinguished by Tyler \& Evans (2003), that is Transmission sense, Means sense and Cause sense, Tyler and Evans use Hilferty's (1999) metaphoric account of through, referring to these senses as metaphorical extensions of the proto-scene of through. This is due to the abstract nature of these senses in comparison to the concrete nature of the previous senses. However, this distinction, as described by Tyler and Evans, is a matter of degree (2003, p. 224).

The Transmission sense is based on the experience of receiving an entity from a sender via another entity. See examples in (17):

(17) a. The comatose patient was fed through a tube.

b. He received a package through the mail.

c. Max gets his blue eyes through his mother.

Example (17a) describes a very similar situation to the proto-scene of through where the LM is characterised as a bounded entity that facilitates the transmission of an entity (the TR). Note that the nominal the comatose patient is not the TR; it is rather a goal or receiver of an action. Examples (17b-c) elaborate the Transmission sense more clearly, which show that the sense has been conventionalised and added to the semantic network of through. The LMs the mail and his mother, although unbounded, are conceptualised as mediums that facilitate the transmission of the TRs package and blue eyes from some (implied) covert entities to some named receivers: he 
(17b) and Max (17c). Tyler and Evans claim that such interpretations of the above examples would not be possible if there was not a "conventional Transmission Sense associated with through" (2003, p. 225).

The Means sense results from a metaphorical conceptualisation of the path element associated with through as a means by which an activity is accomplished. This is shown in examples (18):

(18) a. To return home, he had to find the path through the jungle.

b. I get my coffee through an on-line retailer.

The spatial bounded LM in (18a) is conceptualised as a means by which the goal of returning home is achieved. Similarly, and by pragmatic strengthening, the non-spatial unbounded LM in (18b) is understood as a means for getting coffee.

According to Tyler \& Evans (2003), the Means sense is distinct from the Transmission sense in that the latter involves a third party (usually an implied entity), whereas the former lacks it. By contrast, for example, in (17b) and (18b), we find the following differences. In (17b), the LM the mail is the medium that facilitates the transmission process of the TR a package which has been supplied by an implied supplier (Source) to a Receiver he (Goal). In (18b), the LM an on-line retailer functions both as a means and a supplier (Source) to facilitate the transmission of the TR coffee to the receiver I (Goal).

In the Cause sense, through "mediates a relation between a situation or state, the TR, and a particular process, the LM, which motivates the TR" (ibid, p. 226). That is, the TR undergoes a state of change because of the path it experiences in the LM. Putting this differently, it is the LM that causes the change in the status of the TR. Consider:

(19) a. The accused murderer's wife was able to remain loyal through her conviction of his innocence. (ibid)

b. The milk went sour through a lack of proper refrigeration. (Hilferty, 1999, p. 359)

c. Computer technology has evolved through constant research. (ibid)

The interpretation of (19a) is that the TR, the state of remaining loyal, is due to the LM's metaphorical influence. Similarly, in (19b-c) the TRs have changed from one state to another because of the TR's exposure to the influence of the LM, i.e. lack of proper refrigeration and constant research. In both cases, the change in the TR is motivated by the path it experiences in the LM.

It is worth pointing that the Cause sense differs from the Means sense in that the former requires the TR and the LM to be processes, events or situations, not entities. Moreover, through with the Cause sense can imply the meaning of "because of" while with the Means sense it implies "via". Lee also identifies the Cause sense and asserts that the examples of through denoting a Cause sense have a "more strongly temporal character than those in which LM is an instrumental entity" (1998, p. 343).

Figure 6 below shows the semantic network of the preposition through posited by Tyler \& Evans (2003). The big shaded circle represents the proto-scene, the empty circles represent the distinct senses and the arrows represent the process of image schema transformation.

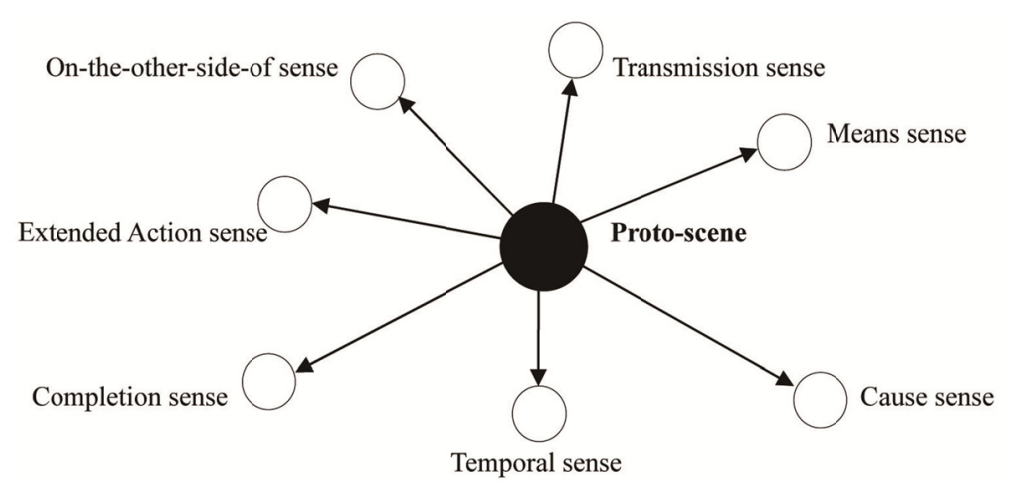

Figure 6. The polysemy network of through 


\subsection{Khilāl vs. through}

The semantic networks of the equivalent spatial prepositions khiläl and through show that they both have the same proto-scene, a TR traversing a bounded LM with an entrance and exit point. With regard to the further senses associated with each, the situation is rather different in the two languages. While Tyler \& Evans (2003) identify or determine the existence of seven distinct senses of the English preposition through, I identify only one sense for the Arabic preposition khilāl. This is the Temporal sense.

With regard to the other senses associated with the English through, which are the Extended Action sense, the On-the-other-side-of sense, the Completion sense, the Means sense, the Transmission sense, and the Cause sense, there was no evidence in the corpus or even elsewhere to support such senses for Arabic khiläl. A quick check on this can be done by translating the relevant examples of Tyler \& Evans (2003) into Arabic. I will not include example of the Means sense as it was discussed in full in section 3.2.

(20) a. Mary worked through the pages of math exercises. [Extended Action sense]

b. My office is located just through that door. [On-the-other-side-of sense]

c. Jane is through with the book. [Completion sense]

d. The comatose patient was fed through a tube. [Transmission sense]

e. The accused murderer's wife was able to remain loyal through her conviction of his innocence. [Cause sense]

Interestingly, the meaning of none of these sentences can be expressed in Arabic by means of the word khiläl. This is probably due to their metaphorical nature. An exception, however, could be (20d). Consider the translation of (20a-e) into (21a-e), respectively. Notice that each Arabic translation corresponding to the examples in (20) has been provided with a literal English translation in (21).
(21) a. ishtaghalat
Mary
Gala tamār-īn
ar-riyāḍiyāt
work.PST.F3SG
Mary on exercise-PL
DEF-math

"Mary worked on the math exercises."

$\begin{array}{llllll}\text { b. yaqa؟ } & \text { maktab-y } & \text { fĩ } & \text { aț-ṭaraf } & \text { al-Pakhar } & \text { min } \\ \text { locate.PRS.3SG } & \text { office-POSS.1SG } & \text { at } & \text { DEF-side } & \text { DEF-other } & \text { from } \\ \begin{array}{l}\text { al-bāb } \\ \text { DEF-door }\end{array} & & & & & \\ \end{array}$

"My office is on the other side of the door."

"Jane completed reading the book."

$\begin{array}{llllll}\text { d. tama } & \text { taghthiyat } & \text { al-marị̣ } & \text { al-fãqid } & \text { San } & \text { al-waȲ̄ } \\ \text { do.PST } & \text { feeding } & \text { DEF-patient } & \text { DEF-absent } & \text { from } & \text { DEF-conscious } \\ \text { Yanțarīq } & \text { inbūbah } & & & & \\ \text { by way } & \text { tube } & & & & \end{array}$

"The comatose patient was fed through a tube."
e. z̧alat
zawjat al-qātil
al-mutaham
mukhilșat-an
remain.PST.F3SG wife
DEF-murderer DEF-convicted
loyal-ACC

la-hu 1-Pīmāni-ha bi-barā?at-ih

to-him for-conviction-POSS.F3SG by-innocence-POSS.M3SG

"The accused murderer's wife was able to remain loyal through her conviction of his innocence."

In (21a, b, c and e), which are the translations of the Extended Action sense, On-the-other-side-of sense, Completion sense and Cause sense of (20a, b, c and e) respectively, no use of khilall is possible. The senses are expressed by other words and/or expressions, e.g., in (21a), the preposition Sala "on" is used, in (21b) the prepositional phrase $f i$ altaraf al?akhar "at the other side of", in (21c) the Completion sense is conveyed by the 
verb Pakmalat "completed" and in (21e) the preposition $l$ - "for" meaning because is used. None of these senses can be expressed by khilāl. As to (21d), there is a possibility of using min khilāl. That is, the prepositional phrase San tarīq "by way of" is one of the meanings denoted by min khilall. However, as discussed in section 3.2, the Means sense is not denoted by khilāl individually.

Therefore, although the Arabic preposition khiläl and the English through bear the same primary sense, they differ in terms of the distinct senses associated with each. For example, khilāl cannot be used to denote the senses of Extended Action, On-the-other-side-of, Completion, Means, Transmission or Cause. Failure or inability to denote such senses by khiläl could be attributed to the restricted experiential correlation between the spatial use and other uses of khiläl. In fact, khilāl is typically used in Classical and Standard Arabic, and not common in the Arabic varieties, such as Iraqi, Libyan, Syrian, Egyptian or Gulf varieties. (Note 15) Consequently, not many associations and uses have been developed or strengthened pragmatically by speakers of Arabic, to derive new senses of khiläl. Another reason could be that khilāl, as outlined earlier is not a true preposition, and originally realised as a noun or adverb of place, denoting time as well. Thus, its use might have been restricted to the spatial and temporal use mostly. However, the possibility of recognising new distinct senses of khiläl is likely in the future, once they are conceptualised and routinized as a daily use.

\section{Conclusion}

This paper has provided a semantic network of the Arabic preposition khiläl. First, a number of basic cognitive notions essential to the understanding of the semantic analysis of prepositions were presented, such as image schema, Trajector and Landmark, and Metaphor. Then, the semantic network of khilāl was developed. Tyler \& Evans' (2003) analysis of through was also reviewed and compared to khilall. They are similar in terms of denoting one spatial proto-scene but different in the variety of senses associated with each.

It has been shown that khiläl is composed of a proto-scene and one distinct sense. The relation between these senses is not random, as might be expected under the classical approach to the polysemy of words in general and prepositions in particular. In fact, the senses are organised systematically in a principled semantic network derived from a central spatial meaning. To demonstrate this, I followed the model of Principled Polysemy proposed by Tyler \& Evans $(2001,2003)$.

Although the semantic network of both equivalent prepositions, through and khilāl, is based on an identical spatial proto-scene, the further distinct senses associated with each proto-scene are different. The difference between these seemingly equivalent words reveals interesting facts in terms of their semantic networks. While the English through can be used to denote the senses of an Extended Action, On-the-other-side-of, Completion, Temporal, Transmission, Means and Cause, the Arabic khiläl can only denote the Temporal sense. The less rich semantic network of khiläl was assumed to be due to the restricted conceptualization process its spatial scene gained by its users in the Arabic speaking world.

\section{Acknowledgments}

This research is supported by Ishik University, Erbil-IRAQ. Also my sincere thanks goes to all those who provided guidance and comments throughout the completion of this work.

\section{References}

Abu-Chacra, F. (2007). Arabic: An Essential Grammar. London: Routledge.

Baalbaki, R. (1995). Al-Mawrid: A Modern Arabic-English Dictionary. Beirut: Dar El-Ilm Lilmalayin.

Badawi, E. M., \& Abdel Haleem, M. (2008). Arabic-English Dictionary of Qur'anic Usage. Leiden: BRILL.

Badawi, E., Carter, M. G., \& Gully, A. (2004). Modern Written Arabic: A Comprehensive Grammar. London: Routledge.

Brugman, C., \& Lakoff, G. (2006). Radial network: cognitive topology and lexical networks. In D. Geeraerts (Ed.), Cognitive Linguistics: Basic Readings (pp. 109-139). Berlin: Mouton de Gruyter. https://doi.org/10.1515/9783110199901.109

Cienki, A. (1999). Some properties and groupings of image schemas. In M. H. Verspoor, K. D. Lee, \& E. Sweetser (Eds.), Lexical and Syntactical Constructions and the Construction of Meaning (pp. 3-15). Amsterdam: John Benjamins.

Croft, W., \& Cruse, D. A. (2004). Cognitive Linguistics. Cambridge: Cambridge University Press. https://doi.org/10.1017/CBO9780511803864

Evans, V., \& Green, M. (2006). Cognitive Linguistics: An Introduction. Edinburgh: Edinburgh University Press. 
Evans, V., \& Tyler, A. (2004). Rethinking English "prepositions of movement": the case of to and through. Belgian Journal of Linguistics: Adpositions of Movement, 18, 247-270.

Falkum, I. L. (2011). The Semantics and Pragmatics of Polysemy: A Relevance-Theoretic Account. PhD thesis, University College London.

Hilferty, J. (1999). Through as a means to metaphor. In de L. Stadler \& C. Eyrich (Eds.), Issues in Cognitive Linguistics (pp. 347-365). Berlin: Mouton de Gruyter. https://doi.org/10.1515/9783110811933.347

Huddleston, R. D., \& Pullum, G. K. (2002). The Cambridge Grammar of the English Language. Cambridge: Cambridge University Press. https://doi.org/10.1017/9781316423530

Johnson, M. (1987). The Body in the Mind: The Bodily Basis of Meaning, Imagination, and Reason. Chicago: University of Chicago Press.

Johnson, M. (2005). The philosophical significance of image schemas. In B. Hampe (Ed.), From Perception to Meaning: Image Schemas in Cognitive Linguistics (pp. 15-34). Berlin: Mouton de Gruyter. https://doi.org/10.1515/9783110197532.1.15

Koffka, K. (1999). Principles of Gestalt Psychology. London: Routledge.

Kouloughli, D. E. (1994). Grammaire de l'arabe d'aujourd'hui. Paris: Pocket.

Lakoff, G. (1987). Women, Fire, and Dangerous Things: What Categories Reveal about the Mind. Chicago: The University of Chicago Press. https://doi.org/10.7208/chicago/9780226471013.001.0001

Lakoff, G. (2006). Conceptual metaphor: the contemporary theory of metaphor. In D. Geeraerts (Ed.), Cognitive Linguistics: Basic Readings (pp. 185-238). Berlin: Mouton de Gruyter. https://doi.org/10.1515/9783110199901.185

Lakoff, G., \& Johnson, M. (1980). Metaphors We Live By. Chicago: The University of Chicago Press.

Langacker, R. W. (1987). Foundations of Cognitive Grammar: Theoretical Prerequisites (vol. 1). Stanford: Stanford University Press.

Langacker, R. W. (2000). Grammar and Conceptualization. Berlin: Mouton de Gruyter.

Lee, D. (1998). A tour through through. Journal of English Linguistics, 26, 333-351. https://doi.org/10.1177/007542429802600404

Lyons, J. (1977). Semantics (vol. 2). Cambridge: Cambridge University Press. https://doi.org/10.1017/CBO9781139165693

Nerlich, B. (2003). Polysemy: past and present. In B. Nerlich, Z. Todd, V. Herman, \& D. D. Clarke (Eds.), Trends in Linguistics: Polysemy: Flexible Patterns of Meaning in Mind and Language (pp. 49-76). Berlin: Mouton de Gruyter. https://doi.org/10.1515/9783110895698

Oakley, T. (2007). Image schemas. In D. Geeraerts \& H. Cuyckens (Eds.), The Oxford Handbook of Cognitive Linguistics (pp. 214-235). Oxford: Oxford University Press.

Peate, J. (2012). A Construction Grammar Approach to Spatial Prepositions in Modern Standard Arabic. PhD thesis, University of Salford.

Quirk, R., Greenbaum, S., Leech, G., \& Svartvik, J. (1985). A Comprehensive Grammar of the English Language. New York: Longman Group Limited.

Rosch, E. (1973). On the internal structure of perceptual and semantic categories. In T. Moore (Ed.), Cognitive Development and the Acquisition of Language (pp. 111-144). New York: Academic Press. https://doi.org/10.1016/B978-0-12-505850-6.50010-4

Rosch, E. (1975). Cognitive representations of semantic categories. Journal of Experimental Psychology: General, 104, 192-233. https://doi.org/10.1037/0096-3445.104.3.192

Rosch, E. (1975). Universals and cultural specifics in human categorisation. In R. Brislin, S. Bochner, \& W. Lonner (Eds.), Cross-Cultural Perspectives on Learning (pp. 177-206). New York: Halsted Press.

Rosch, E., \& Mervis, C. B. (1975). Family resemblances: Studies in the internal structure of categories. Cognitive Psychology, 4, 573-605. https://doi.org/10.1016/0010-0285(75)90024-9

Ryding, K. C. (2005). A Reference Grammar of Modern Standard Arabic. Cambridge: Cambridge University Press. 
Saeed, S. T. (2014). The Syntax and semantics of Arabic spatial Ps. Newcastle and Northumbria Working Papers in Linguistics, 20, 44-66.

Schmid, H. (2007). Entrenchment, salience and basic levels. In D. Geeraerts \& H. Cuyckens (Eds.), The Oxford Handbook of Cognitive Linguistics (pp. 117-138). Oxford: Oxford University Press.

Smith, E. E., Shoben E., \& Rips, L. (1974). Structure and process in semantic memory: A featural model for semantic decisions. Psychological Review, 81, 214-241. https://doi.org/10.1037/h0036351

Talmy, L. (1975). Figure and ground in complex sentences. Proceedings of the First Annual Meeting of the Berkeley Linguistics Society. Berkeley: Berkeley Linguistics Society, 419-430.

Taylor, J. R. (2003). Linguistic Categorization (3rd ed.). Oxford: Oxford University Press.

Tyler, A., \& Evans, V. (2001). Reconsidering prepositional polysemy networks: the case of over. Language, 77, 724-765. https://doi.org/10.1353/lan.2001.0250

Tyler, A., \& Evans, V. (2003). The Semantics of English Prepositions: Spatial Scenes, Embodied Meaning and Cognition. Cambridge: Cambridge University Press. https://doi.org/10.1017/CBO9780511486517

Ungerer, F., \& Schmid, H. (1996). An Introduction to Cognitive Linguistics. New York: Addison Wesley Longman.

Wehr, H. (1976). A Dictionary of Modern Written Arabic (3rd ed.). New York: Spoken Language Services.

Wertheimer, M. (1958). Principles of perceptual organization. In D. C. Beardslee \& M. Wertheimer (Eds.), Readings in Perception (pp. 115-135). New York: van Nostrand.

Wortabet, W. T. (1888). Arabic-English Dictionary. Cairo: Al-Muktataf Printing Office.

\section{Notes}

Note 1. For a syntactic analysis of these elements, including khiläl, and a distinction between true-prepositions and non-true prepositions in Arabic, the reader is referred to Saeed (2014).

Note 2. The arabiCorpus is authorised by Brigham Young University, USA. It includes, at the time of writing, 173,600,000 words cited from various texts and/or genres, such as Qur'an, newspapers, modern literature, nonfiction, Egyptian colloquial and premodern. It is accessible at www.arabicorpus.byu.edu.

Note 3. See also Lyons (1977: 550 ff) and Nerlich (2003) for further discussion of polysemy.

Note 4. Gestalt psychology was a movement in psychology that appeared at the end of $19^{\text {th }}$ century. It has provided inspiration for several concepts used in cognitive linguistics. For further details on Gestalt psychology see Koffka (1999) and Wertheimer (1958).

Note 5. Note that image schemas are conventionally written in uppercase.

Note 6. See Cienki (1999), Johnson (2005), Evans and Green (2006) and Oakley (2007) for more details of the properties of image schema.

Note 7. For a detailed account of work on metaphor and theories of metaphors, such as Conceptual Metaphor Theory, see Lakoff and Johnson's Metaphors We Live By (1980).

Note 8 . The following abbreviations are used in the glosses: $\mathrm{ACC}=$ accusative, $\mathrm{DEF}=$ definite, $\mathrm{DU}=$ dual, $\mathrm{F}=$ feminine, $\mathrm{GEN}=$ genitive, $\mathrm{M}=$ masculine, $\mathrm{NOM}=$ nominative, $\mathrm{PST}=$ past, $\mathrm{PL}=$ plural, $\mathrm{POSS}=$ possessive, $\mathrm{PRS}=$ present, $\mathrm{SG}=$ singular, $1=$ first person, $2=$ second person, $3=$ third person. I use the dash $(-)$ to separate both affixes and clitics from the stems and the period (.) to separate multiple categories represented by one morpheme or item.

Note 9. The Arabic texts are romanised according to the Standard Arabic Technical Transliteration System (SATTS) adopted by the American Library Association/ United States Library of Congress. It is available at www.loc.gov/catdir/cpso/romanization/arabic.pdf.

Note 10. For the nominative, accusative and genitive case, unless they are pronounced I do not represent them in the glosses.

Note 11. Although the temporal use of khilāl is remarkable much more than the spatial use, this however does not entail that the temporal sense is the primary sense. The temporal sense, in fact, is interpreted or based on a spatial sense (see the interpretation of (2a)). 
Note 12. "The Invariance Principle hypothesizes that image-schema structure is always preserved by metaphor" (Lakoff, 2006, p. 200).

Note 13. See Tyler \& Evans' (2001) analysis of over and the several clusters its semantic network includes.

Note 14. The Completion sense leaves open whether the activity involved has been fully completed or only partially.

Note 15. I asked many native Arabic speakers of these varieties whether khilāl is commonly or regularly used in their varieties in their daily uses. The answer of not using khilāl was almost unanimous.

\section{Copyrights}

Copyright for this article is retained by the author(s), with first publication rights granted to the journal.

This is an open-access article distributed under the terms and conditions of the Creative Commons Attribution license (http://creativecommons.org/licenses/by/4.0/). 